\title{
BACTERIAL LUMINESCENCE: IN VIVO AND IN VITRO RESPONSE TO $X$ IRRADIATION
}

\author{
A. P. JACOBSON \\ Department of Environmental and Industrial Health, School of Public Health, \\ University of Michigan, Ann Arbor, Michigan 48104, U.S.A. \\ Received 29 June 1970
}

\begin{abstract}
Bacterial luminescence is suppressed immediately by $\mathrm{X}$ rays and recovers promptly thereafter. This effect is similar in vivo and in vitro, and any disparities are attributed to physicochemical differences between the two sample types. Continuous measurement of dissolved oxygen in samples suggests depletion of oxygen is not responsible for this radiation response. These measurements do show a transient increase of oxygen uptake by bacteria during exposure. Comparisons such as these should be useful in further studies towards identifying the radiosensitive component(s).
\end{abstract}

Luminescence of Photobacterium fischeri is immediately suppressed by $\mathrm{X}$-rays and recovers promptly thereafter ${ }^{1,2}$ ). The mechanism for this response is unknown. However, it is known that the luminous reactions require oxygen ${ }^{3}$ ). Further, the oxygen content of cells and tissues is suppressed during irradiation ${ }^{4,5}$ ). Thus, lowered oxygen tension of luminescent systems during irradiation would explain the suppressed luminescence observed. The re-equilibration of oxygen after exposure would explain recovery of luminescence which is also observed.

As a first step toward understanding the mechanism of luminescence suppression by X-rays, this response has been measured in vivo and in vitro simultaneously with continuous measurements of dissolved oxygen.

An aluminum irradiation chamber couples a galvanic cell oxygen analyzer and a light guide. The distal end of the latter attaches to a shielded photomultiplier ${ }^{6,7}$ ). For radiation studies, the chamber is moved opposite to an X-ray beam port.

Whole cells of Photobacterium fischeri (ATCC 7744) suspended in buffered saline were used for in vivo studies. Cell concentrations were adjusted to $2 \times 10^{9}$ cells per milliliter. For in vitro studies, clarified, cell free extracts were prepared from lysed cells. Excess amounts of reduced nicotine adenine dinucleotide (NADH), flavin mononucleotide $(\mathrm{FMN})$ and decanal were added to extract aliquots immediately prior to an experiment. The methods 
TABLE 1

Luminescence values for 6 important luminescent characteristics from fig. 1 are compared in vivo and in vitro for 4 consecutive samples (columns 1-4) on 3 different days (a, b, c); successive determinations of the same characteristic of luminescence vary between 6 and $10 \%$; values are presented as arbitrary luminescence units $\left(1 \mathrm{ALU}=1 \times 10^{-8} \mathrm{~A}\right)$; rates are expressed as $\mathrm{ALU} / \mathrm{sec}^{-1}$

\begin{tabular}{|c|c|c|c|c|c|c|c|c|c|}
\hline \multirow[b]{2}{*}{$\begin{array}{l}\text { Luminescent } \\
\text { characteristic }\end{array}$} & \multirow[b]{2}{*}{ Experiment } & \multicolumn{4}{|c|}{ in vitro } & \multicolumn{4}{|c|}{ in vivo } \\
\hline & & $t 1$ & 2 & 3 & 4 & 1 & 2 & 3 & 4 \\
\hline \multirow[t]{3}{*}{ Initial intensity } & a & 3.90 & 3.72 & 3.70 & 3.65 & 2.32 & 2.35 & 2.35 & 2.16 \\
\hline & $\mathrm{b}$ & 3.30 & 3.20 & 3.10 & 3.22 & 1.86 & 2.48 & 2.36 & 2.15 \\
\hline & $\mathrm{c}$ & 3.30 & 3.25 & 3.35 & 3.10 & 1.91 & 1.91 & 1.86 & 1.72 \\
\hline \multirow{3}{*}{$\begin{array}{l}\text { Maximum } \\
\text { suppression rate }\end{array}$} & a & 0.17 & 0.16 & 0.19 & 0.16 & 0.12 & 0.12 & 0.14 & 0.12 \\
\hline & b & 0.14 & 0.15 & 0.15 & 0.15 & 0.08 & 0.11 & 0.10 & 0.11 \\
\hline & c & 0.16 & 0.16 & 0.16 & 0.15 & 0.11 & 0.09 & 0.09 & 0.08 \\
\hline \multirow[t]{3}{*}{ Total suppression } & a & 1.59 & 1.41 & 1.52 & 1.42 & 1.94 & 1.90 & 1.95 & 1.73 \\
\hline & b & 1.45 & 1.34 & 1.27 & 1.19 & 1.89 & 1.82 & 1.76 & 1.59 \\
\hline & $\mathrm{c}$ & 1.65 & 1.37 & 1.71 & 0.96 & 1.81 & 1.74 & 1.71 & 1.78 \\
\hline \multirow{3}{*}{$\begin{array}{l}\text { Latent period } \\
\text { (in seconds) }\end{array}$} & a & 1 & 1 & 1 & 1 & 33 & 36 & 50 & 52 \\
\hline & b & 1 & 1 & 1 & 1 & 21 & 28 & 28 & 25 \\
\hline & $\mathrm{c}$ & 1 & 1 & 1 & 1 & 10 & 10 & 10 & 10 \\
\hline \multirow{3}{*}{$\begin{array}{l}\text { Maximum recovery } \\
\text { rate }\end{array}$} & a & 0.41 & 0.37 & 0.36 & 0.33 & 0.011 & 0.015 & 0.009 & 0.008 \\
\hline & $b$ & 0.31 & 0.29 & 0.30 & 0.31 & 0.006 & 0.005 & 0.006 & 0.004 \\
\hline & $\mathrm{c}$ & 0.29 & 0.27 & 0.30 & 0.25 & 0.011 & 0.012 & 0.012 & 0.011 \\
\hline \multirow[t]{3}{*}{ Final intensity } & a & 3.90 & 3.72 & 3.70 & 3.65 & 1.37 & 1.55 & 1.49 & 1.13 \\
\hline & b & 3.30 & 3.22 & 3.15 & 3.25 & 0.89 & 1.19 & 1.13 & 0.95 \\
\hline & c & 3.30 & 3.28 & 3.25 & 3.10 & 1.60 & 1.58 & 1.51 & 1.45 \\
\hline
\end{tabular}

of sample preparation have been reported ${ }^{8}$ ). Control cell or extract samples emit luminescence essentially constant for $20 \mathrm{~min}$ or longer.

When irradiated ${ }^{9}$ ), luminescence of both cells and extracts is suppressed within seconds, attains a lower, somewhat steady state, and recovers after the exposure. The essential comparisons are shown in table 1 and illustrated in fig. 1.

Luminescence is suppressed faster in vitro than in vivo. During the latter portion of exposure, in vitro luminescence usually recovers slightly while in vivo luminescence continues to fall slowly. After exposure, recovery in vitro is vigorous and immediate; in vivo it is delayed and slow. The slight recovery noted in vitro during exposure seems to be related to the overshoot of luminescence after exposure. If recovery does not occur during exposure, no overshoot is observed thereafter (dashed line, fig. 1). The overshoot is 


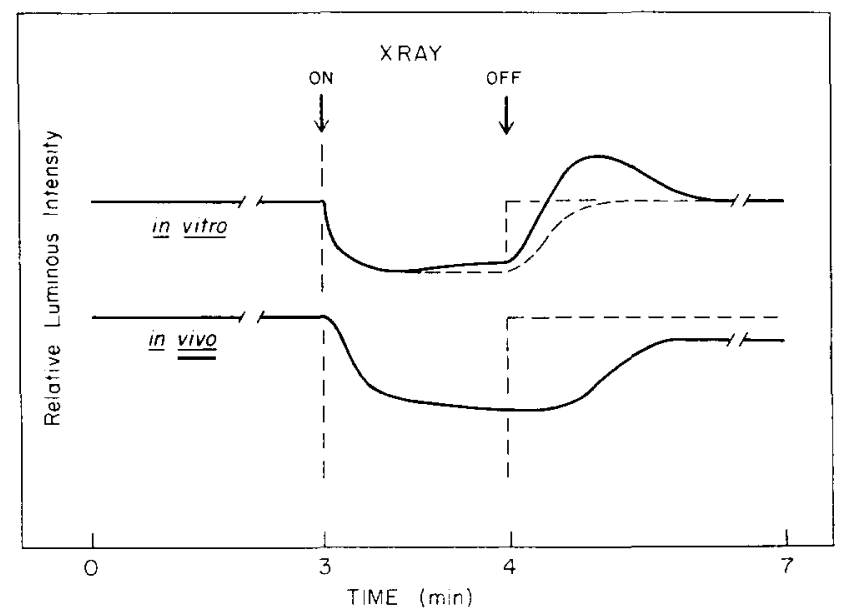

Fig. 1. Comparisons of luminescence in vivo and in vitro before, during, and after irradiation. At the onset of exposure, luminescence is suppressed faster in vitro than in vivo. Later during exposure, the in vitro system recovers slightly while in vivo a slow, continuous fading is observed. Total suppression at the end of an exposure is always greatest in vivo. After exposure, recovery in vitro begins immediately, is vigorous, and, unlike the in vivo system, is complete. If recovery during exposure does not occur in vitro, the recovery wave does not follow as indicated by the dashed line.

similar to that noted in cell samples following periods of anoxia $\left.{ }^{3}\right)$. Both systems regain steady state luminescence within 3 or $4 \mathrm{~min}$. Recovery in vitro is complete; in vivo it is seldom complete.

The differences of response to X-rays by in vivo and in vitro luminescence are undoubtedly related to the physicochemical differences between the two systems. To explain, the in vitro system is devoid of membranes and associated structures, has excess luminescence intermediates (NADH, FMN, and aldehyde), and a high protein concentration. By contrast, in vivo system membranes are intact, cytochrome activity is normal, and luminescence intermediates are present in much lower endogenous concentrations. Cells contribute less than $1 \%$ of the total sample volume in vivo ${ }^{2}$ ). This difference alone should alter the chemistry during irradiation, since most of the radiation-induced reactions will occur in saline rather than in the homogeneous protein solution of in vitro samples.

One can speculate that intact cell membranes will retard the entry of radiotoxins such as hydrogen peroxide. Data show that suppression of luminescence occurs more slowly in vivo than in vitro. Excess substrates in vitro should reduce the total suppression of luminescence by replacement if these substrates are radiolabile. In fact, table 1 shows less suppression in vitro than in vivo. Further, these excess substrates should contribute to 
TABLE 2

Rates of oxygen uptake before, during, and after irratiation of different solutions

\begin{tabular}{|c|c|c|c|c|c|c|c|c|c|c|}
\hline \multirow{3}{*}{$\begin{array}{l}\text { Expt. } \\
\text { No. }\end{array}$} & \multirow{3}{*}{ Solution } & \multirow{3}{*}{$\begin{array}{l}\text { Example } \\
\text { No. }\end{array}$} & \multicolumn{7}{|c|}{ Dissolved oxygen $(\mathrm{mg} / 1 \cdot \mathrm{sec}) \times 10^{-3}$} & \multirow{3}{*}{$\begin{array}{c}(k) \\
\text { Probe } \\
\text { sensitivity } \\
(\mathrm{A} / \mathrm{mg} \cdot \mathrm{l}) \\
\times 10^{-7}\end{array}$} \\
\hline & & & \multicolumn{3}{|c|}{$\begin{array}{l}\text { Total oxygen } \\
\text { consumption }\end{array}$} & \multicolumn{4}{|c|}{$\begin{array}{l}\text { Oxygen consumption } \\
\text { by bacteria alone }\end{array}$} & \\
\hline & & & $S_{1}$ & $S_{2}$ & $S_{3}$ & $A$ & $B$ & $C$ & $D$ & \\
\hline 1 & $\begin{array}{l}\text { Typical } \\
\text { in vitro } \\
\text { samples }\end{array}$ & $\begin{array}{l}a \\
b \\
c\end{array}$ & $\begin{array}{l}1.7 \\
1.7 \\
1.6\end{array}$ & $\begin{array}{l}9.1 \\
8.6 \\
8.3\end{array}$ & $\begin{array}{l}1.7 \\
1.7 \\
1.6\end{array}$ & - & $\begin{array}{l}- \\
-- \\
-\end{array}$ & $\begin{array}{l}- \\
- \\
-\end{array}$ & $\begin{array}{l}- \\
- \\
-\end{array}$ & 3.4 \\
\hline 2 & Saline & & 1.4 & 3.2 & 1.4 & - & - & - & - & 3.9 \\
\hline 3 & $\begin{array}{l}\text { Saline } \\
\text { Saline }+10^{-3} \mathrm{M} \\
\text { cysteine }\end{array}$ & $\begin{array}{l}a \\
b\end{array}$ & $\begin{array}{l}1.7 \\
1.7 \\
1.7\end{array}$ & $\begin{array}{r}3.8 \\
19.2 \\
21.3\end{array}$ & $\begin{array}{l}1.7 \\
1.7 \\
1.7\end{array}$ & $\begin{array}{l}- \\
-\end{array}$ & $\begin{array}{l}- \\
-\end{array}$ & - & $\begin{array}{l}- \\
-\end{array}$ & 3.4 \\
\hline 4 & $\begin{array}{l}\text { Saline } \\
\text { Saline }+ \\
\text { heat killed } \\
\text { cells }\end{array}$ & $\begin{array}{l}a \\
b \\
c\end{array}$ & $\begin{array}{l}1.1 \\
1.1 \\
1.1 \\
1.1\end{array}$ & $\begin{array}{l}3.9 \\
4.0 \\
5.3 \\
4.4\end{array}$ & $\begin{array}{l}0.8 \\
0.8 \\
0.9 \\
0.9\end{array}$ & $\begin{array}{l}-- \\
- \\
-\end{array}$ & $\begin{array}{l}- \\
- \\
-\end{array}$ & $\begin{array}{l}- \\
- \\
-\end{array}$ & $\begin{array}{l}- \\
- \\
-\end{array}$ & 3.6 \\
\hline 5 & $\begin{array}{l}\text { Saline } \\
\text { Typical } \\
\text { in vivo } \\
\text { samples }\end{array}$ & $\begin{array}{l}\mathrm{a} \\
\mathrm{b}\end{array}$ & $\begin{array}{l}1.7 \\
4.6 \\
4.8\end{array}$ & $\begin{array}{r}4.1 \\
10.2 \\
12.3\end{array}$ & $\begin{array}{l}1.7 \\
4.5 \\
3.8\end{array}$ & $\begin{array}{l}- \\
2.9 \\
3.1\end{array}$ & $\begin{array}{l}- \\
6.1 \\
8.2\end{array}$ & $\begin{array}{l}- \\
2.8 \\
2.1\end{array}$ & $\begin{array}{l}- \\
+3.2 \\
+5.1\end{array}$ & 4.1 \\
\hline 6 & $\begin{array}{l}\text { Saline } \\
\text { Typical } \\
\text { in vivo } \\
\text { samples }\end{array}$ & & $\begin{array}{l}1.7 \\
9.2\end{array}$ & $\begin{array}{r}3.6 \\
15.7\end{array}$ & $\begin{array}{l}1.7 \\
9.8\end{array}$ & $\overline{7.5}$ & $\overline{12.1}$ & $\overline{8.1}$ & -4.6 & 4.2 \\
\hline 7 & $\begin{array}{l}\text { Saline } \\
\text { in vivo }\end{array}$ & & $\begin{array}{l}1.6 \\
3.8\end{array}$ & $\begin{array}{l}2.0 \\
6.2\end{array}$ & $\begin{array}{l}1.6 \\
3.1\end{array}$ & $\overline{2.2}$ & $-\overline{4.2}$ & - & $\overline{-} 2.0$ & 5.7 \\
\hline 8 & $\begin{array}{l}\text { Saline } \\
\text { Typical } \\
\text { in vivo } \\
\text { samples }\end{array}$ & $\begin{array}{l}\mathrm{a} \\
\mathrm{b} \\
\mathrm{c}\end{array}$ & $\begin{array}{r}1.4 \\
11.2 \\
11.2 \\
10.4\end{array}$ & $\begin{array}{r}2.2 \\
12.5 \\
15.6 \\
13.4\end{array}$ & $\begin{array}{r}1.4 \\
8.6 \\
10.4 \\
9.5\end{array}$ & $\begin{array}{l}- \\
9.8 \\
9.8 \\
9.0\end{array}$ & $\begin{array}{l}-\overline{10.3} \\
13.4 \\
11.2\end{array}$ & $\begin{array}{l}- \\
7.2 \\
9.0 \\
8.1\end{array}$ & $\begin{array}{l}- \\
-0.5 \\
+3.6 \\
+2.2\end{array}$ & 3.5 \\
\hline
\end{tabular}

Total oxygen consumption represents oxygen uptake by the probe and cells ( $S_{1}$ and $S_{3}$ ). In addition, oxygen uptake by radiation-induced reactions occurs during exposure $\left(S_{2}\right)$. $A, B$, and $C$ represent oxygen uptake by bacteria alone before, during, and after exposure, respectively. The net effect of radiation on cellular oxygen uptake is given under column $N$ and is determined by subtracting $A$ from $B$.

rapid replacement of luminescence intermediates after exposure. The data support this.

Typical oxygen probe data for several types of solutions are given in table 2 together with probe sensitivities $(k)$ [determined by calibration $\left.\left.{ }^{7}\right)\right]$ 
for each of eight experiments. Also, for each calibration, data are given for the rate of oxygen consumption by the probe alone, i.e., $S_{1}$ and $S_{3}$, in cellfree saline. In this medium, $S_{2}$ measures the rate of oxygen uptake during irradiation by the probe and by radiation-induced reactions $(P+R)$. These values are used to calculate the various rates of oxygen uptake due to cells or solute additions to saline for the various experiments [for example, $\left.A=S_{1}-P, B=S_{2}-(P+R)\right]$.

Probe sensitivities vary somewhat because it is difficult to install the thin polyethylene membranes onto the probes with equal tautness each time. Presumably, a very tightly stretched membrane will allow more rapid diffusion of oxygen to the electrode surfaces than a membrane not so tightly installed.

In table 2, Experiment No. 1, oxygen uptake rates $S_{1}, S_{2}$, and $S_{3}$ should be compared with the corresponding values for saline in Experiment No. 2. Oxygen uptake is roughly 3 times greater during exposure $\left(S_{2}\right)$ for in vitro samples than for saline.

In Experiment No. 3, the addition of millimolar cysteine substantially increases oxygen uptake in irradiated saline. The addition of other substances also increases oxygen uptake during exposure, but not to such an extent. For example, when in vivo samples are heat-killed, oxygen uptake during exposure is only slightly higher than for unadulterated saline (Experiment No. 4).

In Experiments No. 5-8, table 2, typical values of oxyten uptake in in vivo samples are given. Comparisons of values for $A, B$, and $C$ shows the changes of cell oxygen uptake before, during, and after exposure. Generally, oxygen uptake by cells increases during exposure and decreases after exposure. To date, 287 in vivo samples have been analyzed. The rate of oxygen uptake by cells was increased during irradiation in $84 \%$ of all samples tested; depressed in the remainder. For an example of the latter, compare $N$, table 2, Experiment No. 8a, with the others. The negative value of $N$ means oxygen uptake was depressed during exposure.

The post-irradiation rate of oxygen uptake by cells was reduced to less than the pre-irradiation rate in $70 \%$ of all samples; $20 \%$ showed an increase; the remainder showed no change ( $A-C$ is positive, $A-C$ is negative, $A-C$ is zero, respectively). Thus, most of the samples showed a transient increase of oxygen uptake; one that disappeared promptly after exposure. Others have reported similar iesults ${ }^{4},{ }^{5}$ ).

The average standard error for a series of consecutive determinations of the rate of oxygen uptake by untreated cells is approximately $5 \%(\bar{x}=$ $0.935+0.020 \mu \mathrm{g} \mathrm{O}_{2} / 1 \mathrm{sec}$ ). The estimate for errors in chemical oxygen determinations in complex media is approximately $6 \%{ }^{7}$ ). 
The luminescent reaction is independent of oxygen concentration above $0.3 \mathrm{vol}^{\circ}$ in vivo and in vitro ${ }^{3}$ ). In no case during these experiments was oxygen reduced to this level. Thus, the depression of luminescence during $\mathrm{X}$ irradiation is not due to measurable anoxia of sample oxygen tension.

These results are particularly significant because they show that some radiation effects appear immediately upon irradiation and recover promptly thereafter. It is also important that these immediate radiation effects result from exposures to low doses. They are first observable within one second at doses less than 100 rad.

\section{References}

1) O. Hug and I. Wolf, Kinetics of open systems applied in radiation biology, in Progress in Radiobiology, Eds. J. S. Mitchell et al. (C. Thomas, Springfield, Illinois, 1956) pp. 23-31 C.

2) C. H. Burns, A. P. Jacobson and G. H. Whipple, Radiation Res. 24 (1965) 494.

3) J. W. Hastings, Anat. Record 22 (1955) 458.

4) A. Vacek et al., Intern. J. Rad. Biol. 8 (1964) 499.

5) R. J. Romani and J. B. Bowers, Nature 197 (1963) 509.

6) A. P. Jacobson, Rev, Sci. Instr. in press (1970).

7) K. H. Mancy and W. C. Westgarth, J. Water Pollution Control Federation 34 (1962) 1037. This device is similar to the Clark electrode and produces a current proportional to the partial pressure of oxygen at the electrodes. Calibration was done by an Alsterberg modification of the Winkler method of determining dissolved oxygen in complex media.

8) C. H. Burns, A. D. Nevill and G. H. Whipple, Analytical Biochem. 5 (1963) 394.

9) General Electric Maxitron 300 operated at $300 \mathrm{kVp}$ and $20 \mathrm{~mA}$; tube target $9 \mathrm{~cm}$ from the mid-line of the irradiation chamber, filtration of the X-ray beam consisted of a $4.75 \mathrm{~mm}$ beryllium tube window and the walls of the chamber (approximately $1 \mathrm{~mm}$ aluminum with $1 \%$ copper); half value layer of the X-ray beam passing through the walls of the chamber was $0.75 \mathrm{~cm}$ aluminum measured by ferrous sulfate dosimetry $\left(G=15.65 \varepsilon=2270\right.$ at $\left.26.8^{\circ} \mathrm{C}\right)$. The dose rate was $6500 \mathrm{rad} / \mathrm{min}$; exposure time was $1 \mathrm{~min}$ in all experiments.

10) Supported by NSF grant GB-3294. 